\title{
Microbiological Quality and Proximate Composition of Bakasang Laor, a Traditional Fermented Fishery Product in Maluku
}

\author{
Ferymon Mahulette*, Tri Santi Kurnia \\ Biology Education Study Program, Faculty of Teacher Training and Education, Universitas Pattimura, Indonesia \\ *Email: ferymonm@gmail.com
}

Submitted: 1 January 2020. Revised: 11 February 2020. Accepted: 20 March 2020

\begin{abstract}
Bakasang laor is one of the traditional fermented fishery products in Maluku, Indonesia. There are two types of bakasang laor, i.e. with and without vinegar. The microbiological research of bakasang processed use laor as raw material has never been done before. The research aimed to analyze the microbiological quality and proximate composition of two types of bakasang laor. The proximate composition can determine the nutritional value of this product for consumption by the community. The sample of bakasang laor was taken from traditional producer in Latuhalat village, Ambon. The total number of halotolerant and coliform bacteria in bakasang laor without vinegar were $1.7 \times 10^{6} \mathrm{CFU} / \mathrm{g}$ and $4.1 \times 10^{6} \mathrm{CFU} / \mathrm{g}$, respectively, while the total of lactic acid bacteria in bakasang laor with vinegar was $6.0 \times 10^{6} \mathrm{CFU} / \mathrm{g}$. The carbohydrate, protein, fat and ash contents of bakasang laor with vinegar was higher than bakasang laor without vinegar. The carbohydrate, protein and fat contents of bakasang laor with vinegar were $19.64 \%, 16.23 \%$, and $2.42 \%$, respectively. Generally, microbiological quality and proximate composition of bakasang laor with vinegar was better than bakasang laor without vinegar. The bacteria that play a role in fermentation can be used as a starter in the fermentation of various food products. The results of this research to improve the quality of this fermentation product in the future.
\end{abstract}

Key words: bakasang laor, coliform, halotolerant bacteria, lactic acid bacteria, proximate composition

How to Cite: Mahulette, F., \& Kurnia, T. S. (2020). Microbiological Quality and Proximate Composition of Bakasang Laor, a Traditional Fermented Fishery Product in Maluku. Biosaintifika: Journal of Biology \& Biology Education, 12 (1), 64-69

DOI: http://dx.doi.org/10.15294/biosaintifika.v12i1.23356

\section{INTRODUCTION}

Fishery product is the main source of protein consumed by people in Maluku. One of the fishery product in this area is laor, a colony of sea worms that swarming periodically in March and April in Maluku Seas (Figure 1a). The worms are usually found in Ambon, Uliaser (Lease) Islands, Ternate, Banda Islands, and Tanimbar with different names. Laor is also found outside the seas of Maluku, such as in Lombok and Sumba (Mahulette, 2020). The worms are often caught abundantly, making their preservation becomes necessary. One of the laor preservation techniques with fermentation is called bakasang laor (Figure 1b), a local wisdom of Maluku communities. This product is used as a food reserve during lean times.

Bakasang consists of bakasang and bakasang laor. Bakasang is processed using viscera of cakalang fish (Katsuwonus pelamis, Lin) as raw material and it is a traditional food consumed by the people in Maluku and North Sulawesi (Purwaningsih et al., 2013), while bakasang laor is processed using laor worm and only consumed by people in Maluku. This fermented product is very popular in the community. In processing bakasang laor, salt and vinegar are usually added, However, in certain conditions, vinegar is not always added in producing bakasang. Bakasang with vinegar (bakasang $\mathrm{V}$ ) uses vinegar and salt as preservatives and bakasang without vinegar (bakasang $\mathrm{NV}$ ) uses only salt. Bakasang laor processing in Ambon Island usually only uses salt, whereas in Uliaser Islands usually uses salt, vinegar, and certain spices. Both have distinct sensory characteristics and different shelf life. The shelf life of bakasang laor $\mathrm{V}$ is usually more than a year (Latumahina, 2011)

The sensory characteristics and shelf life of a fermented product are strongly influenced by microbial diversity. Bakasang fermentation occurs spontaneously and involves various types of microbes. The main microbes involved in fishery product fermentation is lactic acid bacteria (LAB) (Noonpakdee et al., 2009). The bacteria belong to the Generally Recognized as Safe (GRAS) category, making it safe to be in a food product (Pringsulaka et al., 2012). Other bacteria are also found in various fermentation product, such as halotolerant and coliform bacteria. Both of these bacteria are pathogenic, so their number is limited in food. The halotolerant bacteria, such as Staphylococcus are able to produce cytotoxin that kill innate immune cells (DuMont et al., 2011). Coliform is often used as an indicator of water and food contaminant (Ananchaipattana et al., 2012) 
A microbiological quality and proximate analysis o bakasang processed using laor as raw material has never been done, even though this fermented product has been consumed for a long time by the community. The objective of this research was to study the microbiological quality and proximate compositions of bakasang laor $\mathrm{NV}$ and bakasang laor $\mathrm{V}$. LAB might potentially produce antimicrobial compounds that function as biopreservative in food to reduce the use of chemical preservatives that are potential health risks (Pringsulaka et al., 2012). Some of these bacteria have been used as probiotics. LAB found in $b a$ kasang laor can be used as a starter to improve the quality of this product and other fermented products. Proximate compositions are used to determine the nutritional value of this product for consumption. Fermented products with high protein content can be used as food substitutes that are sufficient for people nutrition.

\section{METHODS}

\section{Processing of Bakasang Laor}

The bakasang laor used in this study was taken from traditional producer in Latuhalat village, Ambon Island consisting of bakasang laor NV and bakasang laor $\mathrm{V}$. The processing of bakasang laor was done by the producer. A total of $2 \mathrm{~kg}$ of laor worms as raw material was put into basin and added with $400 \mathrm{~g}$ of table salt then dried in the sun for 10 hours. The basin was covered with mosquito net, so that it was not entered by flies and other insects. The laor worm was then put in a bottle after drying. The bottle was closed and laor was allowed to fermentation at room temperature for 12 weeks to produce bakasang laor (without vinegar). In the processing of bakasang laor with vinegar, $5 \%$ of vinegar was added (Latumahina, 2011). The research was conducted in Laboratory of Biology Education, Pattimura University.

\section{Isolation and Characterization of Bacteria in $\mathrm{Ba}$ - kasang Laor}

A total of $25 \mathrm{~g}$ of sample was mixed with $225 \mathrm{ml}$ of sterile peptone solution and homogenized using a stomacher bags. One $\mathrm{ml}$ of the homogenized and diluted samples were poured into Petri dishes, then de Man, Rogosa and Sharp Agar (MRSA) (KGaA, Germany) containing $1 \% \mathrm{CaCO}_{3}$ and $3 \% \mathrm{NaCl}$ were poured on it and incubated at room temperature for 48 hours (Fan \& Song, 2013). For isolation of halotolerant and coliform bacteria, $100 \mu \mathrm{l}$ from the homogenate samples were inoculated on Mannitol Salt Agar (MSA) (KGaA, Germany) (Kateete et al., 2010) and Eosin Methylene Blue Agar (EMBA) (KGaA, Germany) (Colclasure et al., 2015), respectively, using the spread plate technique with a sterile L-shape glass rod then incubated at $37^{\circ} \mathrm{C}$ for 24 hours. All the isolates obtained were stained with Gram and spore staining and catalase test (Fan \& Song, 2013).

\section{Physicochemical Analysis}

Physicochemical analysis was carried out at the beginning and after 12 week of fermentation. The $\mathrm{pH}$ measurement was conducted using $\mathrm{pH}$ meter (CT 6022 Kedida, China). The proximate analysis was performed based on Lee et al. (2013). The protein and fat content were determined using Kjeldahl and Soxhlet methods. The total of carbohydrate was determined using carbohydrate by difference method. The moisture and ash contents were measured using the gravimetric methods. The proximate analysis was conducted in the Integrated Laboratory of IPB University.

\section{RESULT AND DISCUSSION}

\section{The Number and Characteristics of Bacteria in Bakasang Laor}

Bacteria play a role in bakasang laor fermentation. The bacteria were also contaminants in the food product so the number was limited. The main bacteria that play a role in bakasang fermentation were lactic acid bacteria (Ingratubun et al., 2013), while contaminant bacteria include halotolerant bacteria, such as Staphylococcus, and coliform bacteria, such as Escherichia and Enterobacter. The main factor influencing the presence of bacteria in fishery fermentation was salt as a preservative. In bakasang laor $V$, vinegar also acts as a preservative that limits microbial growth.

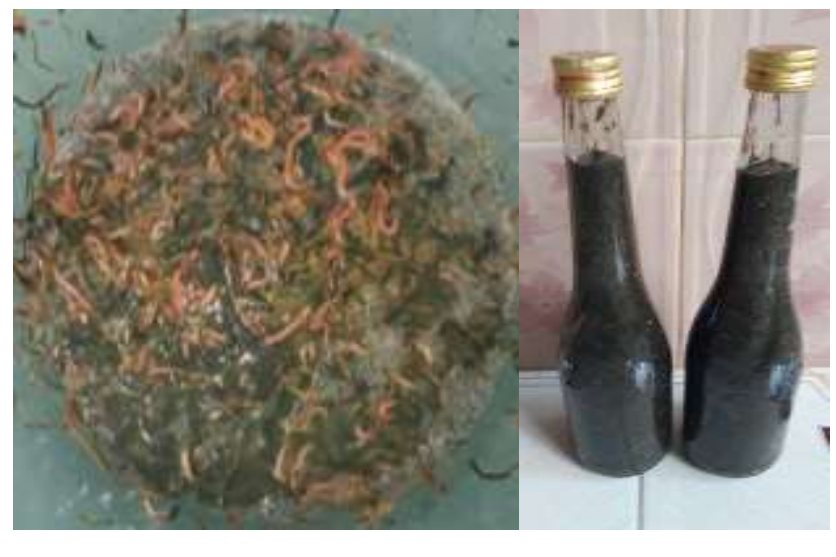

(a)

(b)

Figure 1. Laor (a), bakasang laor (b)

A total of 7 isolates of bacteria were isolated from bakasang laor $\mathrm{NV}$, and 6 isolates from bakasang laor $\mathrm{V}$. Isolates found in bakasang laor NV were also found in bakasang laor $\mathrm{V}$, except on EMBA media. The highest total number of bacterial colonies in EMBA media was $3.0 \times 10^{5} \mathrm{CFU} / \mathrm{g}$. (Table 1). Two 
bacterial colonies was found on MRSA media. One of these colonies were white color and negative catalase so that were considered as lactic acid bacteria. Total of lactic acid bacteria in bakasang laor $\mathrm{V}$ was higher than bakasang laor NV after fermentation for 12 weeks. Vinegar is a weak acid which can reduce the $\mathrm{pH}$ of medium and support the growth of lactic acid bacteria. The characteristics of colonies in EMBA media that had different color can be used to identify the types of coliform (Table 1).

Table 1. Macroscopic characteristics of bacteria isolated from bakasang laor

\begin{tabular}{|c|c|c|c|c|c|c|c|}
\hline \multirow{2}{*}{ Sample } & \multirow{2}{*}{ Media } & \multirow{2}{*}{ Code } & \multicolumn{3}{|c|}{ Characteristics of Colony } & \multirow{2}{*}{ Catalase test } & \multirow[t]{2}{*}{ Total of Colony (CFU/g) } \\
\hline & & & Forms & Pigments & Margins & & \\
\hline \multirow[t]{7}{*}{ Without vinegar } & MRSA & BK-01 & Circular & Yellow & Entire & + & $1.0 \times 10^{5}$ \\
\hline & & BK-02 & Circular & White & Entire & - & $2.0 \times 10^{4}$ \\
\hline & MSA & BK-03 & Circular & Yellow & Entire & + & $1.1 \times 10^{5}$ \\
\hline & & BK-04 & Circular & Pink & Entire & + & $3.0 \times 10^{4}$ \\
\hline & & BK-05 & Circular & White & Entire & + & $3.0 \times 10^{4}$ \\
\hline & EMBA & BK-06 & Circular & Red & Entire & + & $2.3 \times 10^{5}$ \\
\hline & & BK-07 & Circular & Green & Entire & + & $1.8 \times 10^{5}$ \\
\hline \multirow[t]{6}{*}{ With vinegar } & MRSA & BK-01 & Circular & Yellow & Entire & + & $4.0 \times 10^{4}$ \\
\hline & & BK-02 & Circular & White & Entire & - & $6.0 \times 10^{4}$ \\
\hline & MSA & BK-03 & Circular & Yellow & Entire & + & $1.0 \times 10^{5}$ \\
\hline & & BK-04 & Circular & Pink & Entire & + & $3.0 \times 10^{4}$ \\
\hline & & BK-05 & Circular & White & Entire & + & $3.0 \times 10^{4}$ \\
\hline & EMBA & BK-08 & Circular & Pink & Entire & + & $3.0 \times 10^{5}$ \\
\hline
\end{tabular}

The result of microscopic characterization showed that the bacteria found in bakasang laor were rods and cocci shaped. These bacteria were grouped into Gram positive and negative bacteria. Two bacterial isolates was found on MRSA media. One of these isolates formed spore, so that it was considered as Bacillus, while the other isolate formed cocci pairs and no spore formation. This last isolate was considered as Leuconostoc. Three bacterial isolates were found on MSA media. The characteristics of these isolates were cocci shape, Gram positive and no spore formation, so they were considered as Staphylococcus. The characteristics of isolates in EMBA media were cocci shape, Gram negative and no spore formation, so they were considered as Enterobacter and Escherichia because they had different colony colors (Table 2). The selected isolates had different shape and sizes (Figure 2).

Table 2. Microscopic characteristics of bacteria isolated from bakasang laor

\begin{tabular}{lllllll} 
Sample & Media & Code & Gram & Spore & Shape of cell & Genus of Bacteria (Estimation) \\
\hline Without vinegar & MRSA & BK-01 & + & + & Rod & Bacillus \\
& & BK-02 & + & - & Cocci & Leuconostoc \\
& MSA & BK-03 & + & - & Cocci & Staphylococcus \\
& & BK-04 & + & - & Cocci & Staphylococcus \\
With vinegar & & BK-05 & + & - & Cocci & Staphylococcus \\
& EMBA & BK-06 & - & - & Rod & Enterobacter \\
& & BK-07 & - & - & Rod & Escherichia \\
& & BK-01 & + & - & Rod & Bacillus \\
& MSA & BK-02 & + & - & Cocci & Leuconostoc \\
& & BK-03 & + & - & Cocci & Staphylococcus \\
& & BK-05 & + & - & Cocci & Staphylococcus \\
& EMBA & BK-08 & - & - & Cocci & Staphylococcus \\
\hline
\end{tabular}




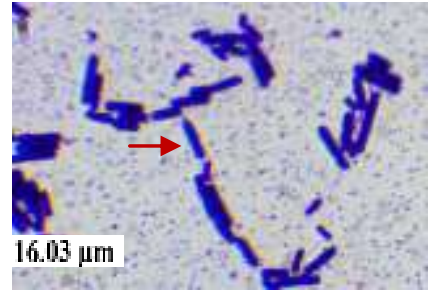

(a)

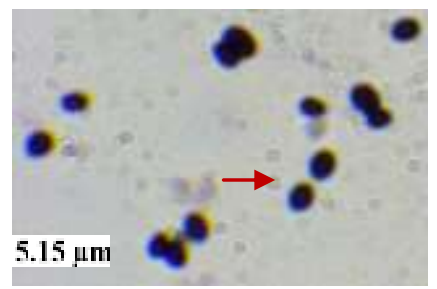

(c)

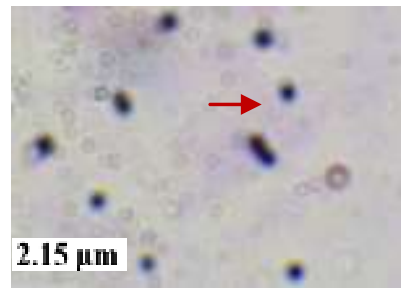

(b)

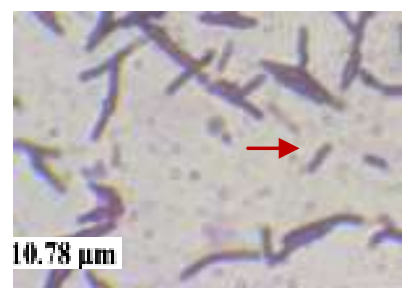

(d)

Figure 2. Microscopic characteristics of bacteria isolated from bakasang laor on different media (Magnification 1000x). Isolates of BK01 and BK02 on MRSA (a,b), BK05 on MSA (c), and BK06 on EMBA (d).

The Changes of Phycochemical Caharacteristics in Bakasang Laor Fermentation

The $\mathrm{pH}$ of both types of bakasang laor were showed noticeable changes as the increase of fermentation time. At the beginning of fermentation, the $\mathrm{pH}$ value of bakasang laor $\mathrm{NV}$ and bakasang laor $\mathrm{V}$ were 6.70 and 5.80 respectively. The $\mathrm{pH}$ value of bakasang laor NV and V sharply decreased at the fourth weeks of fermentation and continued to reach 5.1 and 4.5 , respectively at the end of fermentation. The decrease was not sharp after 4 weeks of fermentation in bakasang laor NV (Figure 3). The high microbial numbers in this fermented product cause the degradation of protein into peptides and volatile base substances more quickly (Purwaningsih et al., 2013). An increase of volatile base substances causes the $\mathrm{pH}$ of bakasang laor to be relatively stable at the end of fermentation.

The $\mathrm{pH}$ value of bakasang laor $\mathrm{V}$ was lower than bakasang laor NV. The accumulation of acid compounds from vinegar causes a more acidic medium in bakasang laor $\mathrm{V}$ and support the growth of lactic acid bacteria. The $\mathrm{pH}$ greatly affects the presence of lactic acid bacteria in a fermentation product. Coccusshaped lactic acid bacteria, such as Leuconostoc usually grow at an optimum $\mathrm{pH}$ above 4.5 , different from Lactobacillus which grow optimally at the $\mathrm{pH}$ below it. The bacteria normally grow in neutral and acid condition ( $\mathrm{pH}$ 5.0-7.0) ( $\mathrm{Li}$ et al., 2012). The $\mathrm{pH}$ of bakasang laor was relatively high compared to the fermentation of other fishery products because there was no addition of carbohydrate source to accelerate the acid compounds formation.

Proximate analysis of both types of bakasang laor at the beginning and after 12 weeks fermentation showed that the moisture of bakasang laor NV in- creased until the end of fermentation, whereas in $b a$ kasang laor $\mathrm{V}$ it decreased. The moisture of bakasang laor $\mathrm{NV}$ at the beginning of fermentation was 38.82 $\%$ then increased to $60.35 \%$ at the end of fermentation, whereas in bakasang laor $\mathrm{V}$, it had decreased from $54.28 \%$ to $51.15 \%$. The moisture content was essential for microbial growth and enzyme activity that play a role in fermentation (Anggo et al., 2015). Laor that used as a raw material in bakasang processing was a sea worm with fragile body segments (Mahulette, 2020). Preservation of bakasang laor using salt only causes very soft and slimy texture which indicates high moisture.

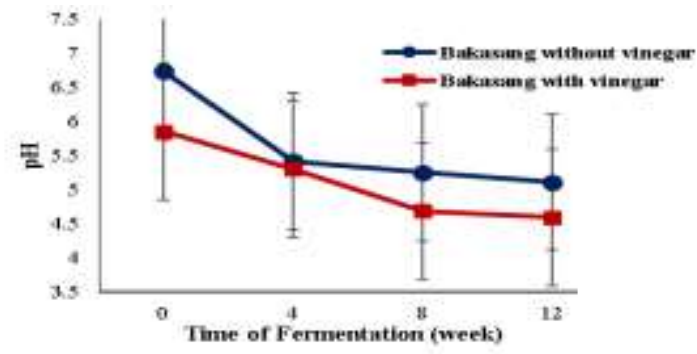

Figure 3. The changes of $\mathrm{pH}$ during bakasang laor fermentation

The protein content of bakasang laor NV was $25.72 \%$ at the beginning of fermentation and then decreased to $15.29 \%$ at the end of fermentation, whereas in bakasang laor $\mathrm{V}$ it increased from $13.45 \%$ to $16.23 \%$. The fat content also decreased in $b a$ kasang laor NV. The fat of bakasang laor NV was $3.62 \%$ at the beginning and then decreased to $0.17 \%$, while the fat content of bakasang laor $\mathrm{V}$ increased from $0.07 \%$ to $2.42 \%$ at the end of fermentation. Bacillus and Staphylococcus were more commonly found in bakasang laor NV. Both of these bacteria 
have high proteolytic and lipolytic activities in fish fermentation (Marti et al., 2010; Marsiello et al., 2016). Tolerance to high salt content causes degradation of protein to amino acids more quickly by Staphylococcus in fermented product (Mahulette et al., 2018b).

Although the carbohydrate content of both types of bakasang laor decreased, it was no significant in $b a$ kasang laor $\mathrm{V}$. The carbohydrate content of bakasang laor $\mathrm{NV}$ at the beginning of fermentation was 26.69
$\%$ then sharply decreased to $16.65 \%$ at the end of fermentation, whereas in bakasang laor $\mathrm{V}$ it had decreased from $21.35 \%$ to $19.64 \%$. Double preservation of fermented product with salt and vinegar causes only a few microbes to grow and utilize carbohydrate as an energy source in bakasang laor $\mathrm{V}$ fermentation. Thus, the carbohydrate, protein and fat contents of bakasang laor $\mathrm{V}$ were higher than bakasang laor $\mathrm{NV}$ at the end of fermentation (Table 3).

Table 3. The result of proximate analysis of bakasang laor at beginning and after 12 week fermentation (wet basis)

\begin{tabular}{|c|c|c|c|c|}
\hline \multirow{3}{*}{ Parameter } & \multicolumn{4}{|c|}{ Time of Fermentation (week) } \\
\hline & \multicolumn{2}{|c|}{ Bakasang laor NV } & \multicolumn{2}{|c|}{ Bakasang laor $\mathrm{V}$} \\
\hline & 0 & 12 & 0 & 12 \\
\hline Moisture (\%) & $38.82 \pm 0.04$ & $60.35 \pm 2.01$ & $54.28 \pm 0.02$ & $51.15 \pm 0.02$ \\
\hline Carbohydrate content (\%) & $26.69 \pm 0.01$ & $16.65 \pm 0.01$ & $21.35 \pm 0.17$ & $19.64 \pm 0.12$ \\
\hline Protein content $(\%)$ & $25.72 \pm 0.23$ & $15.29 \pm 1.01$ & $13.45 \pm 0.25$ & $16.23 \pm 0.12$ \\
\hline Fat content $(\%)$ & $3.62 \pm 0.07$ & $0.18 \pm 0.23$ & $0.07 \pm 0.02$ & $2.42 \pm 0.01$ \\
\hline Ash content $(\%)$ & $5.15 \pm 0.11$ & $7.53 \pm 0.02$ & $10.85 \pm 0.02$ & $10.64 \pm 0.03$ \\
\hline
\end{tabular}

Lactic acid bacteria found in bakasang laor can increase the collection of microbes that play a role in fermentation of fishery product. These bacteria can be used as a starter to improve the quality of bakasang laor and other fermented product. The large amount of contaminant bacteria in bakasang laor indicates that this fermented product was less safe for consumption. Aseptic processing was needed to reduce the amount of contaminant bacteria in this product. The nutrition value of bakasang laor $\mathrm{V}$ was higher than bakasang laor $\mathrm{NV}$ at the end of fermentation. Bakasang laor $\mathrm{V}$ can be used as food substitutes to provide nutrition for people. The result of this study can be used as a reference to improve quality of $b a$ kasang laor as one of the popular local food in Malu$\mathrm{ku}$.

\section{CONCLUSION}

Bakasang laor without vinegar and with vinegar have different microbiological characteristics and proximate composition. The total number of halotolerant and coliform bacteria was higher in bakasang laor without vinegar, while the total number of lactic acid bacteria was higher in bakasang laor with vinegar. The carbohydrate, protein, fat and ash contents of bakasang laor with vinegar was higher than bakasang laor without vinegar. Generally, microbiological quality and proximate composition of bakasang laor with vinegar was better than bakasang laor without vinegar.

\section{ACKNOWLEDGEMENTS}

The researcher was very grateful to the head of the Integrated Laboratory of IPB University that have analyzed a part of this research, and Faculty of Teacher Training and Education, Pattimura University, who has provided the funding for the researchers to conduct this research.

\section{REFERENCES}

Ananchaipattana, C., Hosotani, Y., Kawasaki, S., Pongsawat, S., Bari, M.D.F., Isobe, S. \& Inatsu, Y. (2012). Bacterial contamination in retail food purchased in Thailand. Food Sci Technol Res, 18(5), 705-712.

Anggo, A. D., Widodo, F.M., Swastawati, F. \& Rianingsih, L. (2015). Changes of amino and fatty acid in anchovy (Stolephorus sp) fermented fish paste with different fermentation periods. Proced Environ Sci, 23, 58-63.

Beek, A.T. \& Brul, S. (2010). To kill or not kill Bacilli: opportunities for food biotechnology. Curr Opinion Biotechnol, 21, 168-174.

Caamano-Antelo, S., Fernandez-No, I.C., Bohme, K., Ezzat-Alnakip, M., Quintela-Baluja, M., BarrosVelazquez, J. \& Calo-Mata, P. (2015). Genetic discrimination of foodborne pathogenic and spoilage Bacillus spp. based on three housekeeping genes. Food Microbiol, 46, 288-298.

Colclasure, V.J. B.S., Thomas, J., Soderquist, M.S., Lynch, T.B.S.,Schubert, N.B.S., Deirdre, S., McCormick, B.S., Urrutia, E.B.S., Knickerbocker, C.B.S., McCord, D.B.S. \& Kavouras, J.H. (2015). 
Coliform bacteria, fabrics, and environment. American J Infect Cont, 43, 154-158.

DuMont, A.L., Nygaard, T.K., Watkins, R.L., Smith, A., Kozhaya, L., Kreiswirth, B.N., Shopsin, B., Unutmaz, D., Voyich, J.M. \& Torres1, V. J. (2011). Characterization of a new cytotoxin that contributes Staphylococcus aureus pathogenesis. Molecular Microbiol, 79(13), 814-825.

Fan, L. \& Song, J. (2013). Antimicrobial microbesbacteriocin producing lactic acid bacteria. In Mendez-Vilas A, Microbial pathogens and strategies for combating them: science, technology and education. Badajoz: Formatex Research Center.

Gad, G.F.M., Aly, R.A. I. \& Ashour, M.S.E. (2011). Microbial evaluation of some non-sterile pharmaceutical preparations commonly used in the Egyptian market. Trop J Pharm Res, 10(4), 437-445.

Gassem, M.A. (2019). Microbiological and chemical quality of traditional salted-fermented fish (HoutKasef) product of Jazan region, Saudi Arabia. Saudi J Biolog Sci, 26, 137-140.

Ingratubun, J.A., Ijong, F.G. \& Onibala, H. (2013). Isolasi dan identifikasi bakteri asam laktat pada bakasang sebagai starter mikrob produk fermentasi. Aquat Sci Manag, 1, 48-56.

Kateete, D.P., Kimani, C.N., Katabazi, F.A., Okeng, A., Okee, M.S., Nanteza A., Joloba, M.L. \& Najjuka F.C. (2010). Identification of Staphylococcus aureus: DNase and Mannitol Salt Agar improve the efficiency of the tube coagulase test. Annals Clinical Microbiol Antimicrob, 9(23), 1-7

Kivisto, A.T. \& Karp, M.T. (2011). Halophilic anaerobic fermentative bacteria. J Biotechnol, 152, 114124.

Lee, H., Cho, B.K., Kim, M.S., Lee, W.H., Tewari, J., Bae, H., Sohn, S.I. \& Chi, H.Y. (2013). Prediction of crude protein and oil content of soybeans using Raman spectroscopy. Sensors Actua B, 185, 694700.

Li, L., Eom, H., Park, J., Seo, E., Ahn, J.E., Kim, T., Kim, J.W. \& Han, N.S.(2012). Characterization of the mayor dehydrogenase related to D-lactic acid synthesis in Leuconostoc mesenteroides subsp. mesenteroides ATCC 8293. Enz Microbiol Tech, 51, 274-279.

Latumahina, M.C.A. (2011). Pengolahan dan komposisi gizi cacing polychaeta di Pulau Ambon. In Jambormias E, Riupassa, P.A (Eds). Seminar Nasional Pengembangan Pulau-pulau Kecil dari
Aspek Perikanan Kelautan dan Pertanian (247253). Bogor: Direktorat Kemahasiswaan Institut Pertanian Bogor.

Mahulette, F. (2020). The swarming and benefits of laor in Moluccas. In Sekiguchi Global Research Association (Eds). Suistainable Shared Growth: Proceeding of The $5^{\text {th }}$ Asia Future Conference (710-715). Manila: Sekiguchi Global Research Association.

Mahulette, F., Mubarik, N.R., Suwanto, A. \& Widanarni. (2018a). Diversity of lactic acid bacterial in inasua fermentation. Iranian J Microbiol, 10(5), 314-323.

Mahulette, F., Mubarik, N.R, Suwanto, A. \& Widanarni. (2018b). Microbiological and physicochemical characteristics of inasua fermentation. Biosaintifika, 10(2), 296-305.

Masiello, S.N., Martin, N.H., Trmčić, A., Wiedmann, M. \& Boor, K.J. (2016). Identification and characterization of psychrotolerant coliform bacteria isolated from pasteurized fluid milk. J Dairy Sci, 99, 1-11.

Marti, M.,Trotonda, M.P.,Tormo-Mas, M.A.,VergaraIrigaray, M., Ambrose., Cheung., Lasa, I. \& Penades, J.R. (2010). Extracellular proteases inhibit protein-dependent biofilm formation in Staphylococcus aureus. Microb Infec, 12, 55-64.

Noonpakdee, W., Jumriangrit, P., Wittayakom, K., Zendo, J., Nakayama, J., Sonomoto, K. \& Panyim, S. (2009). Two-peptide bacteriocin from Lactobacillus plantarum PMU 33 strain isolated from som-fak, a Thai low salt fermentation fish product. Asia Pac J Mol Biol Biotechnol, 17(1), 19-25.

Pringsulaka, O., Thongngam, N., Suwannasai, N., Atthakor, W., Pothivejkul, K. \& Rangsiruji A. (2012). Partial characterization of bacteriocins produced by lactic acid bacteria isolated from Thai fermented meat and fish product. Food Contr, 23, 547-551.

Purwaningsih, S., Santosa, J. \& Garwan, R. (2013). Perubahan fisiko-kimiawi, Mikrobiologis dan histamine bakasang ikan cakalang (Katsuwonus pelamis, Lin) selama fermentasi dan penyimpanan. J Teknol Industri Pangan, 24(2), 1-9.

Yuliana, N., Koesoemawardhani, D., Susilawaty. \& Kurniati, Y. (2018). Lactic acid bacteria during fish fermentation (rusip). MOJ Food Process Technol, 6(2), 211-216. 